\title{
APLIKASI PENCATATAN PIUTANG MENGGUNAKAN METODE POSTING LANGSUNG PADA JNE PILANG EL 88 CIREBON
}

\author{
Antik Rahma Dayanti ${ }^{1}$, Suwandi $^{2}$, Marsani Asfi ${ }^{3}$, Widya Jati Lestari ${ }^{4}$ \\ Universitas Catur Insan Cendekia \\ J1. Kesambi 202, Kota Cirebon, Jawa Barat Tlp : (0231) 220250 \\ e-mail : antikrahmadayanti@gmail.com¹, suwandi@cic.ac.id², marsani.asfi@cic.ac.id ${ }^{3}$, \\ widya.jatilestari@cic.ac.id ${ }^{4}$
}

\begin{abstract}
ABSTRAK
Saat ini di JNE Pilang El 88 Cirebon belum mempunyai sistem khusus untuk pengolahan data piutang, pencatatannya hanya menggunakan media buku dan Microsof Word yang dilakukan oleh bagian piutang. Hal tersebut dinilai kurang efektif karena proses merekap data piutang cukup menyita waktu, tak jarang terjadi keterlambatan penagihan, dan kesulitan saat melakukan pencarian data piutang pelanggan. Dalam upaya menjaga piutang pemilik perlu memperhatikan pengendalian internal didalamnya. Tujuan melakukan pengendalian internal adalah untuk pengolahan dan penyajian data yang dapat dipercaya. Metode pengumpulan data yang digunakan penulis dalam tugas akhir ini yaitu menggunakan metode penelitian deskriptif, yang terdiri dari wawancara, observasi dan studi pustaka. Bahasa pemograman yang digunakan adalah PHP (Hypertext Preprocessor) sedangkan dalam perancangangannya menggunakan Flowmap, Diagram Konteks, Data Flow Diagram (DFD), dan Entity Relationship Diagram (ERD). Hasil dari penelitian ini adalah sebuah aplikasi berupa Sistem Informasi Akuntansi Pencatatan Piutang Menggunakan Metode Posting Langsung pada JNE Pilang El 88 Cirebon. Adapun dengan dibuatnya aplikasi ini dapat memudahkan bagian piutang dalam merekap data piutang menjadi lebih efektif. Selain itu, dengan dibuatnya aplikasi multi user dapat membantu pemilik melakukan pengawasan terhadap transaksi piutang sehingga pengendalian internal perusahaan berjalan dengan baik.
\end{abstract}

Kata Kunci : Aplikasi, Sistem Akuntansi, Piutang, Metode Posting Langsung

\begin{abstract}
Currently, JNE Pilang El 88 Cirebon does not yet have a special system for processing receivables data, the recording only uses book media and Microsoft Word which is carried out by the accounts receivable department. This is considered less effective because the process of recapitulating the receivables data is quite time-consuming, not infrequently there are delays in billing, and difficulties when searching for customer receivables data. In an effort to maintain receivables, the owner needs to pay attention to internal controls in it. The purpose of performing internal control is to process and present reliable data. The data collection method used by the author in this final project is using descriptive research methods, which consist of interviews, observations and literature studies. The programming language used is PHP (Hypertext Preprocessor) while in the design it uses Flowmap, Context Diagram, Data Flow Diagram (DFD), and Entity Relationship Diagram (ERD). The result of this research is an application in the form of an Accounting Information System for Recording Receivables Using the Direct Posting Method at JNE Pilang El 88 Cirebon. As for making this application, it can make it easier for the accounts receivable department to recapitulate accounts receivable data to be more effective. In addition, by making a multiuser application, it can help owners monitor receivable transactions so that the company's internal control runs well.
\end{abstract}

Keywords: Application, Accounting System, Accounts Receivable, Direct Posting Method

Aplikasi Pencatatan Piutang Menggunakan Metode Posting Langsung pada JNE Pilang El 88 Cirebon(Antik Rahma Dayanti, Suwandi, Marsani Asfi, Widya Jati Lestari) 


\section{PENDAHULUAN}

Teknologi dan informasi saat ini telah berkembang di berbagai aspek kehidupan. Semakin cepat perkembangannya berdampak terhadap banyak bidang yang diperlukan bagi kelangsungan hidup umat manusia. Salah satu hasil dari perkembangan teknologi yaitu sebuah benda yang tidak berwujud seperti software. Singkatnya, software merupakan perangkat lunak atau program yang menginstruksikan komputer, handphone untuk melakukan tugas tertentu oleh penggunanya.

PT Tiki Jalur Nugraha Ekakurir (JNE) merupakan salah satu perusahaan yang bergerak di bidang jasa kurir ekspress dan logistik yang berpusat di Jakarta. Tingkatan JNE sendiri terdiri dari pusat, cabang, dan agen. JNE Pilang EL 88 merupakan salah satu agen yang berada di wilayah Kota Cirebon yang beralamat di jalan Wiratama No.55. Dalam meningkatkan penjualannya, JNE Pilang EL 88 melakukan pemberian piutang kepada pelanggannya. Dalam pencatatan piutangnya, JNE Pilang EL 88 melakukannya secara manual yaitu mencatat dan mengarsipkannya pada buku. Hal tersebut dinilai kurang efektif karna proses perekapan cukup menyita waktu, terkadang terjadi keterlambatan penagihan, serta mengalami kesulitan saat melakukan pencarian data piutang pelanggan yang diperlukan. Berdasarkan uraian latar belakang masalah tersebut, maka penulis ingin melakukan penelitian yang disajikan dengan judul : "Aplikasi Pencatatan Piutang Menggunakan Metode Posting Langsung pada JNE Pilang EL 88 Cirebon".

\section{KAJIAN PUSTAKA}

\subsection{Sistem Informasi Akuntansi}

Sistem Informasi Akuntansi adalah sebuah sistem yang memproses data dan transaksi guna menghasilkan informasi yang bermanfaat untuk merencanakan mengendalikan dan mengoperasikan bisnis. Untuk dapat menghasilkan informasi yang diperlukan oleh para pembuatan keputusan, sistem informasi akuntansi harus melaksanakan tugas-tugas sebagai berikut :

1. Mengumpulkan transaksi dan data lain dan memasukkannya ke dalam sistem.

2. Memproses data transaksi.

3. Menyimpan data untuk keperluan masa mendatang.

4. Menghasilkan informasi yang diperlukan dengan mmeproduksi laporan, atau memungkinkan para pemakai untuk melihat sendiri data yang tersimpan di komputer.

5. Mengendalikan seluruh proses sedemikian rupa sehingga informasi yang dihasilkan akan dapat dipercaya. (Krismiaji, 2015)

\subsection{Piutang}

\subsubsection{Pengertian Piutang}

Menurut Hery (2015) mendefinisikan istilah piutang adalah mengacu pada sejumlah tagihan yang akan diterima oleh perusahaan (umumnya dalam bentuk kas) dari pihak lain, baik sebagai akibat penyerahan barang dan jasa secara kredit. Sedangkan menurut Warren, et al (2015) piutang (receiveble) mencakup seluruh uang yang diklaim terhadap entitas lain, termasuk perorangan, perusahaan, dan organisasi lain. Piutang-piutang ini biasanya merupakan bagian yang signifikan dari total aset lancar.

\subsubsection{Metode Pencatatan Piutang}

1. Metode posting langsung

Metode posting langsung ke dalam kartu piutang dibagi menjadi dua golongan berikut ini :

a. Metode posting harian :

1) Posting langsung ke dalam kartu piutang dengan tulisan tangan. Dalam metode ini, piutang di posting langsung setiap hari secara rinci kedalam kartu piutang.

2) Posting langsung ke dalam kartu piutang dan pernyataan piutang dengan kartu piutang sebagai tembusannya atau tembusan lembar kedua berfungsi sebagai kartu piutang.

b. Metode posting periodik

1) Posting Ditunda

Dalam keadaan tertentu posting ke dalam kartu piutang akan lebih praktis bila dilakukan sekaligus setelah faktur terkumpul dalam jumlah yang banyak. Dengan demikian faktur penjualan yang diterima dari bagian penagihan, oleh bagian piutang disimpan sementara, menunggu beberapa hari, untuk nantinya secara sekaligus di posting ke dalam kartu piutang secara bersamasama dalam sekali periode posting dengan menggunakan mesin pembukuan. 
2) Metode Penagihan Bersiklus

Dalam metode ini, selama sebulan, media disortasi dan diarsipkan menurut nama pelanggan. Pada akhir bulan dilakukan kegiatan posting yang meliputi: (1) posting media yang dikumpulkan selama sebulan tersebut ke dalam pernyataan piutang dan kartu piutang. (2) menghitung dan mencatat saldo setiap kartu piutang.

2. Metode Konvensional

Dalam metode ini posting ke dalam kartu piutang dilakukan atas dasar data yang dicatat dalam jurnal. (Mulyadi,2008).

\section{METODE PENELITIAN}

Metode Penelitian yang digunakan adalah :

\section{Field Research (Penelitian Lapangan)}

a. Observasi Langsung

Yaitu metode pengumpulan data dengan cara mengamati dan mencatat dokumen-dokumen penerimaan kas atas pendapatan jasa terkait perubahan HGB menjadi SHM pada Kantor ATR/BPN Kota Cirebon.

b. Wawancara Yaitu metode pengumpulan data dengan cara berkomunikasi secara langsung atau tidak langsung kepada sumber data.

\section{Library Research (Studi Kepustakaan)}

Yaitu kegiatan untuk menghimpun informasi yang relevan dengan topik atau masalah yang menjadi obyek penelitian. Informasi tersebut dapat diperoleh dari buku-buku, karya ilmiah, internet dan sumbersumber lain.

\section{HASIL DAN PEMBAHASAN}

4.1. Flowchart yang Berjalan

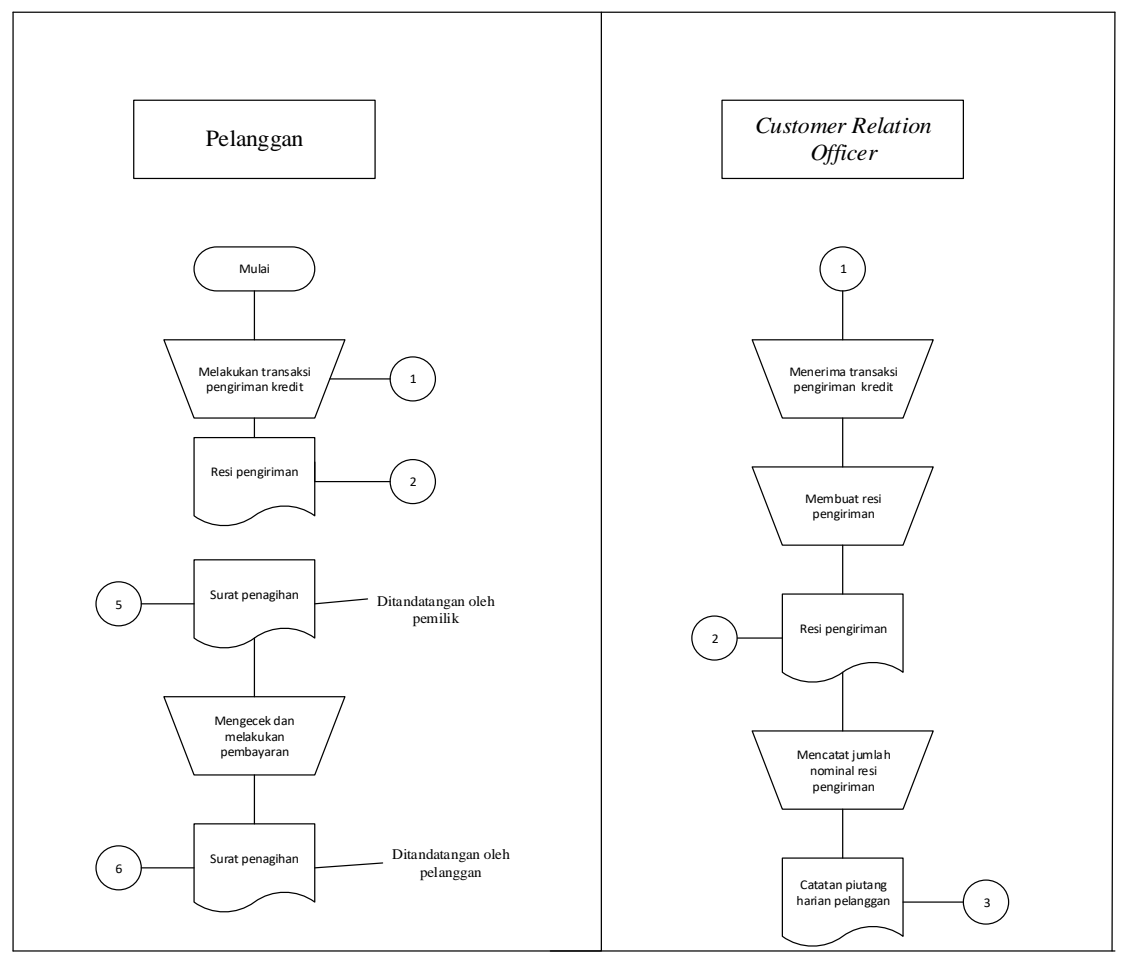

Gambar 1. Flowchart Pencatatan Piutang Pada JNE Pilang El 88 Cirebon

Aplikasi Pencatatan Piutang Menggunakan Metode Posting Langsung pada JNE Pilang El 88 Cirebon(Antik Rahma Dayanti, Suwandi, Marsani Asfi, Widya Jati Lestari) 


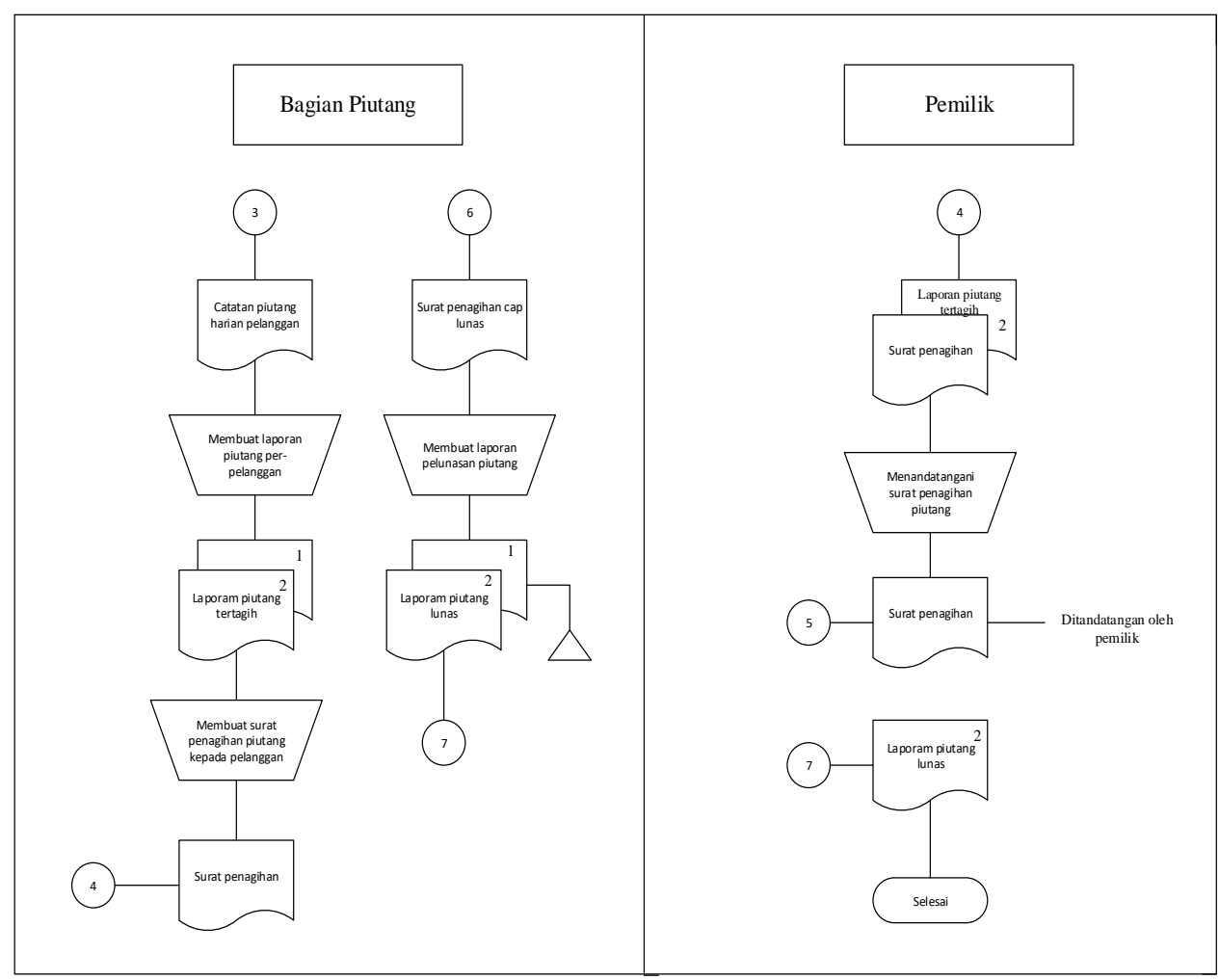

Gambar 2. Flowchart Pencatatan Piutang Pada JNE Pilang El 88 Cirebon

Prosedur narasi sistem akuntansi pencatatan piutang yang sedang berjalan pada JNE Pilang El 88 sebagai berikut :

\section{Pelanggan}

Dimulai dari pelanggan yang melakukan transaksi pembayaran secara kredit, lalu pelanggan akan menerima resi pengiriman. Setelah jatuh tempo pembayaran, pelanggan akan menerima surat tagihan dari bagian piutang lalu mengecek dan melakukan pembayaran serta menandatangani surat penagihan tersebut.

\section{Customer Relation Officer (CRO)}

CRO menerima transaksi pengiriman paket dari pelanggan dan membuat resi pengiriman. Setelah itu mencatat jumlah nominal transaksi piutang pada buku harian piutang.

\section{Bagian Piutang}

Pada saat penagihan bagian piutang merekap jumlah transaksi piutang pelanggan berdasarkan catatan buku harian piutang yang dikelola oleh CRO. Seteleh direkap bagian piutang membuat laporan piutang perpelanggan lalu membuat surat penagihan yang diserahkan kepada pelanggan yang ditandatangani oleh pemilik. Ketika pelanggan sudah melunasi pembayaran bagian piutang akan mencap lunas surat penagihan dan membuat laporan piutang lunas.

\section{Pemilik}

Pemilik akan menandatangani surat tagihan yang dibuat oleh bagian piutang, kemudian pemilik menerima laporan pelunasan pelanggan dari bagian piutang. 


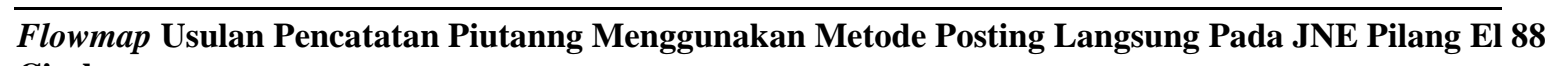
Cirebon

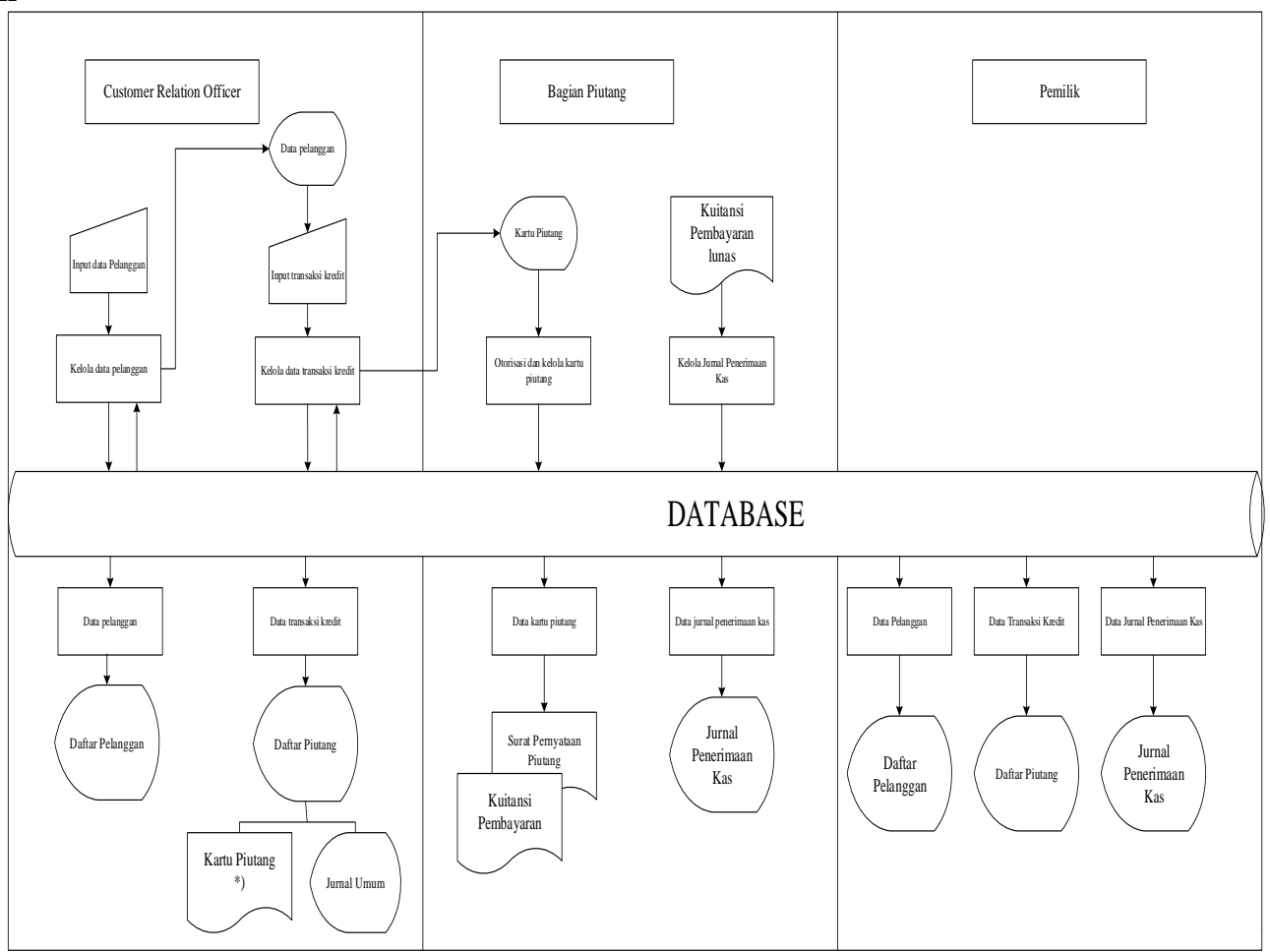

Gambar 3. Flowmap Usulan Pencatatan Piutang Menggunakan Metode Posting Langsung Pada JNE Pilang El 88 Cirebon

\subsection{Diagram Konteks}

Adapun diagram konteks aplikasi pencatatan piutang pada JNE Pilang El 88 Cirebon seperti pada gambar 4.4 berikut :

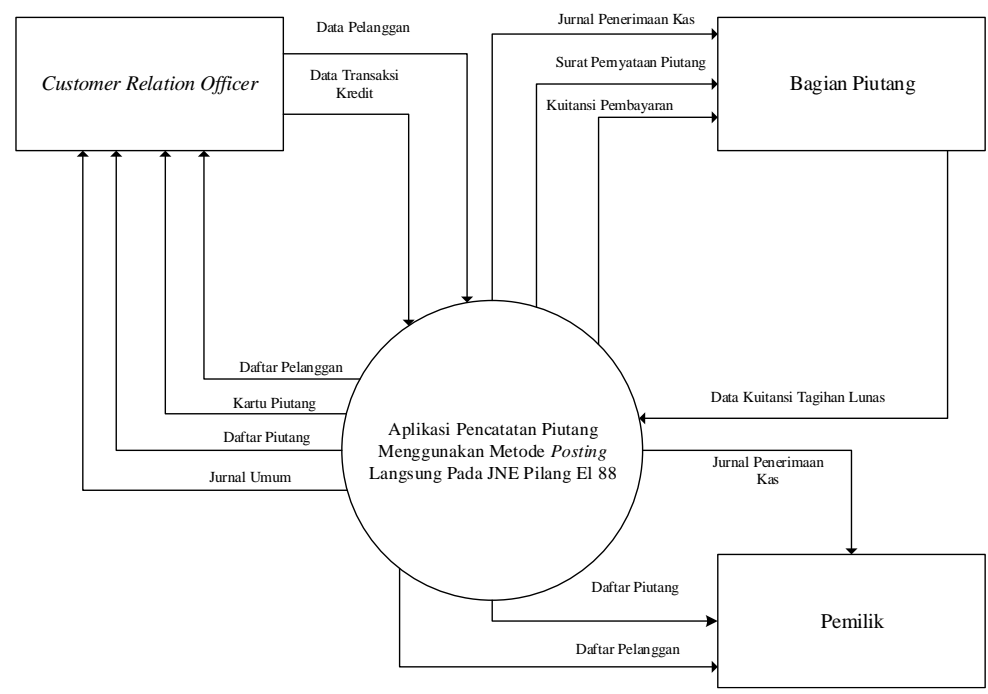

Gambar 4. Diagram Konteks Pencatatan Piutang Menggunakan Metode Posting Langsung pada JNE Pilang El 88 Cirebon

Aplikasi Pencatatan Piutang Menggunakan Metode Posting Langsung pada JNE Pilang El 88 Cirebon(Antik Rahma Dayanti, Suwandi, Marsani Asfi, Widya Jati Lestari) 
Pada gambar 4. Diagram Konteks diatas menggambarkan dari Sistem Pencacatan Piutang Menggunakan Metode Posting Langsung Pada JNE Pilang El 88. Bagian yang terkait yaitu Customer Relation Officer (CRO), bagian piutang, dan pemilik. CRO menginputkan data pelanggan, data transaksi kredit, kemudian menghasilkan output berupa daftar pelanggan, daftar piutang, kartu piutang piutang, dan jurnal umum. Selanjutnya bagian piutang mengotorisari kartu piutang dan menghasilkan output berupa surat pernyataan piutang dan kuitansi pembayaran. Kemudian pemilik dapat mengakses daftar pelanggan, daftar piutang, jurnal penerimaan kas yang sudah dikelola oleh bagian piutang.

\subsection{Diagram Hubungan Antar Entitas (Entity Relationship Diagram / ERD)}

Dalam sistem Akuntansi Pencatatan Piutang Menggunakan Metode Posting Langsung Pada JNE Pilang El 88 Cirebon melibatkan beberapa entitas yang saling berhubungan satu sama lain. Hubungan antar entitas tersebut dapat dilibatkan pada gambar di bawah ini :
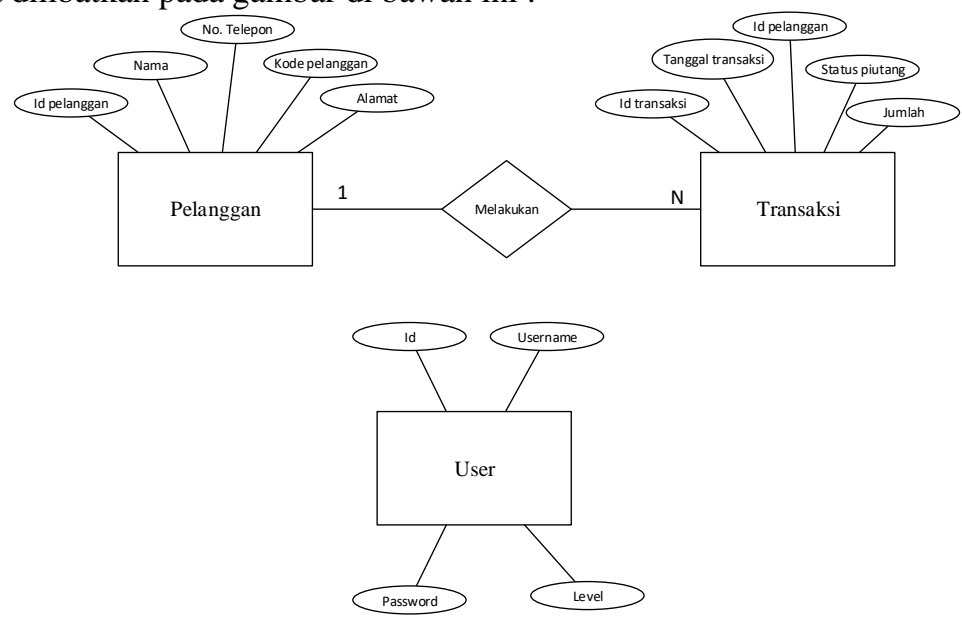

Gambar 5. ERD Pencatatan Piutang Mengunakan Metode Posting Langsung Pada JNE Pilang El 88 Cirebon

\subsection{Tampilan Program}

\section{Form Login}

Form login pada gambar 6 digunakan untuk mengakses aplikasi berdasarkan hak akses yang dimilikinya. Form login terdiri dari input username, input password, dan tombol options untuk memilih level berdasarkan jabatannya.

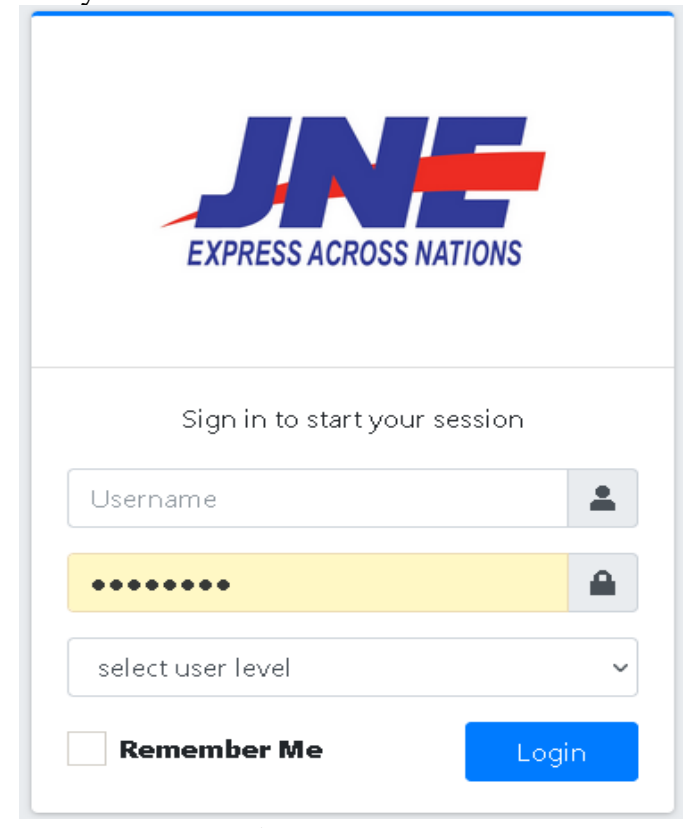

Gambar 6. Form Login 
2. Menu Utama Customer Relation Officer (CRO)

Menu utama CRO pada gambar 7 merupakan form yang menampilkan menu-menu yang dapat diakses oleh CRO. Tampilan menu CRO berisi tambah pelanggan, daftar pelanggan, tambah transaksi, daftar piutang, menu kartu piutang, dan jurnal umum.



Gambar 7. Menu Utama CRO

\section{Kartu Piutang}

Kartu piutang pada gambar 8 merupakan data piutang yang telah diposting langsung oleh CRO atas transaksi piutang pelanggan yang berisikan besaran transaksi setiap harinya.

\begin{tabular}{|c|c|c|c|c|c|}
\hline \multicolumn{6}{|c|}{$\begin{array}{c}\text { KARTU PIUTANG } \\
\text { JNE Pilang El } 88 \\
\text { Jl. Wiratama No. } 55 \text { - Pilang } \\
\text { Telp. }\{0231\} 18804499 \text { jnepilangel88@gmail.com }\end{array}$} \\
\hline $\begin{array}{l}\text { Kode Pelanggan } \\
\text { Nama Pelanggan } \\
\text { No. Telepon } \\
\text { Alamat }\end{array}$ & $\begin{array}{l}\text { : C-001 } \\
: \text { Sheika Dena } \\
: \text { 0811911411238 } \\
: \text { JI. Pilang Mas Garden No }\end{array}$ & & & & \\
\hline Tanggal & Keterangan & Ref & \multicolumn{2}{|c|}{ Mutasi } & Salda \\
\hline $2021-07-19$ & Id Transaksi No.10 & & 869.000 & - & 869.000 \\
\hline $2021-07-20$ & Id Transaksi No.12 & & 133.000 & - & 1.002 .000 \\
\hline $2021-07-21$ & Id Transaksi No.16 & & 168.000 & - & 1.170 .000 \\
\hline $2021-07-22$ & Id Transaksi No.18 & & 20.5 .000 & - & 1.375 .000 \\
\hline $2021-07-23$ & Id Transaksi No.21 & & 176.000 & - & 1.551 .000 \\
\hline $2021-07-24$ & Id Transaksi No.24 & & 839.000 & - & 2.390 .000 \\
\hline
\end{tabular}

Gambar 8. Kartu Piutang

Aplikasi Pencatatan Piutang Menggunakan Metode Posting Langsung pada JNE Pilang El 88 Cirebon(Antik Rahma Dayanti, Suwandi, Marsani Asfi, Widya Jati Lestari) 


\section{KESIMPULAN DAN SARAN \\ 5.1 Kesimpulan}

Kesimpulan yang diperoleh setelah melalui tahap-tahap perancangan dari pembuatan perangkat lunak Aplikasi Pencatatan Piutang Menggunakan Metode Posting Langsung pada JNE Pilang El 88 adalah sebagai berikut : Sistem Informasi Akuntansi pencatatan piutang yang berjalan pada JNE Pilang El 88 masih bersifat konvensional, dengan mengimplementasikan sistem aplikasi berbasis web dapat memudahhakan CRO dalam mengelola pencatatan transaksi piutang dalam jumlah pelanggan yang banyak serta memudahkan bagian piutang dalam melakukan penagihan. Oleh karena itu, pemanfaatan manajemen waktu CRO dan bagian piutang dalam menyelesaiakan pekerjaannya menjadi efektif dan efisien.

\subsection{Saran}

Untuk mengembangkan aplikasi ini di kemudian hari ada beberapa hal yang perlu diperhatikan yaitu:

1. Sebagai bahan acuan pemilik dalam mengevaluasi penjualannya, aplikasi ini dapat dikembangkan dengan menambah fitur seperti grafik piutang perusahaan.

2. Menghindari keterlambatan penagihan piutang dan keterlambatan pembayaran oleh pelanggan sebaikanya aplikasi ini dapat dikembangkan dengan menambah fitur notifikasi bagi penggunanya saat piutang jatuh tempo.

3. Untuk pengembangan lebih lanjut, disarankan aplikasi ini dapat dikembangkan dengan menghasilkan laporan piutang. Dengan laporan piutang maka manajemen perusahaan dapat mengetahui posisi piutang sehingga dapat mengambul kebijakan keuangan yang tepat.

\section{DAFTAR PUSTAKA}

[1] Mulyadi, 2016. Sistem Akuntansi, Jakarta : Salemba Empat

[2] Krismiaji. 2015. Sistem Informasi Akuntansi. Edisi Keempat. Penerbit Unit Penerbit dan Percetakan Sekolah Timggi Ilmu Manajemen YKPN.

[3] Hans Kartikahadi., dkk. 2016. Akuntansi keuangan berdasarkan SAK berbasis IFRS buku 1. Jakarta : Salemba Empat.

[4] Hery. 2016. Akuntansi Dasar 1 \& 2. Jakarta: Grasindo.

[5] Al Fatta, Hanif. 2017. Analisis dan Perancangan Sistem Informasi. Yogyakarta: ANDI.

[6] Indrajani. 2015. Database Design (Case Study All in One). Jakarta: PT Elex Media Komputindo.

[7] Ruhmana, Futikha, Dewi, and Lilis Ardini. (2017) "Pengaruh perputaran piutang, persediaan dan skala perusahaan terhadap priofitabilitas perusahaan Property "Jurnal Ilmu Riset Akuntansi"

[8] Asfi, M., Suwandi, S., \& Setiadi, P. H. (2019). SISTEM INFORMASI AKUNTANSI PENDAPATAN DENGAN METODE POSTING LANGSUNG : (Studi Kasus: Toko Oong). Accounting and Management Journal, 3(2), 77-84. https://doi.org/10.33086/amj.v3i2.1406 